\title{
Encapsulation of Probiotic Bacillus coagulans for Enhanced Shelf Life
}

\author{
Kavita Rajesh Pandey, Babu Vamanrao Vakil* \\ G. N. Khalsa College of Arts, Science and Commerce, Matunga (E.), Mumbai, India.
}

\section{ARTICLE INFO}

Article history:

Received on: 09/02/2017

Accepted on: 10/05/2017

Available online: 14/08/2017

Key words:

Probiotics, stability studies,

Bacillus coagulans,

Encapsulation, Spray drying,

Freeze drying.

\begin{abstract}
Probiotic strains must be able to withstand industrial manufacturing conditions and retain maximum viability and functionality during storage. Probiotic cells also have to survive the harsh mileu in the stomach and small intestine. Encapsulating probiotic cells with suitable agents helps them resist such adverse conditions and minimize the loss in viability. Four encapsulation materials were evaluated in the current study: Fructooligosaccharide (FOS), Maltodextrin (MD), Skimmed milk (SM) and Xanthan gum (XG). Cells were encapsulated using two commonly used techniques, spray drying (SD) and freeze drying (FD). Accelerated stability study on formulations was carried out as per ICH guidelines. Parameters like viability, water activity, residual moisture content, etc. were assessed to determine the shelf life. Viability losses in encapsulation by FD in the range of $4-27.5 \%$ were lower than by SD technique (the range of $19-40 \%$ ). Approximately $60-80 \%$ of B. coagulans cells survived both SD and FD processing conditions, which is higher than $40-50 \%$ viability reported for Lactobacillus strains. Protective abilities of different encapsulation materials were in the order of: SM $>$ FOS $>$ MD $>$ XG. Scanning electron microscopy of the encapsulated probiotics demonstrated that in the course of 90 days, surface of encapsulated particles developed some roughness, indicating their likely less stability.
\end{abstract}

\section{INTRODUCTION}

Probiotics have been defined as live microorganisms which when consumed in adequate amounts confer health benefit to the host [1]. In the recent past, there is explosive growth of probiotic-based health products, mostly in the form of fermented dairy products or dietary supplements. Several health benefits have been claimed of probiotic consumption [2, 3]. Before probiotics can be delivered to consumers, microbial cultures must be able to withstand the industrial downstream processing. In addition, they must retain viability and functionality during storage and transportation as dehydrated, frozen or freeze-dried biomass suitable for application. Loss of viability during storage is a major limiting factor for effectiveness of many probiotic products $[4,5]$. Therefore, viability of probiotic bacteria in a product at the point of consumption (desirable levels, approximately $10^{8}-10^{9} \mathrm{CFUg}^{-1}$ ) is an important consideration for their efficacy [6-8]. Bacterial survival during storage, is adversely affected by factors such as temperature, moisture content, Water activity $\left(\mathrm{a}_{\mathrm{w}}\right)$, nature and quality of carrier media, exposure to

* Corresponding Author

Babu Vamanrao Vakil, G. N. Khalsa College of Arts, Science and Commerce, Matunga (E.), Mumbai, India.Email: bvvakil @ gmail.com light and oxygen, etc. [9]. Once consumed by the humans, probiotics also need to be protected against degradation in the stomach especially at low $\mathrm{pH}$ and aggressive intestinal fluids $e . g$. bile and pancreatic juice [10]. Coating the probiotic cells with a suitable encapsulation material for providing protection against adverse physicochemical changes, is currently receiving considerable attention [11-13]. Encapsulation assists in achieving higher cell densities, improved substrate utilization, acts as a barrier against release of entrapped cells and also minimizes the contamination [14]. The encapsulation material may be damaged by mechanical rupture or dissolution of the substance and subsequent release of entrapped cells [15]. An array of encapsulating materials has been used to immobilize probiotics. Examples include a variety of polymers, fats, waxes, pectin, $\kappa-$ carrageenan, alginate, gellan gum, locust bean gum, galactooligosaccharide (GOS), maltodextrin (MD), skimmed milk (SM), xanthan gum (XG) and fructooligosaccharide (FOS) etc. [16-18]. Biopharmaceutical products during storage tend to deteriorate as they age, but they are considered to be stable as long as their characteristics remain within the certain specified limits as laid down in the regulatory guidelines and manufacturer's specifications [7]. The number of days that the product remains stable at the specified storage conditions, as recommended by the manufacturer, is referred to as the shelf life [6]. 
Parameters like water activity $\left(\mathrm{a}_{\mathrm{w}}\right)$, residual moisture content are used as indirect methods of assessing the stability of a formulation whereas viability in terms of colony forming units (CFU), can be used as direct method [18] .The quality of encapsulated material can be also judged by physical methods like electron microscopy to study the smoothness of the walls of the particles beads. The smoother outer surfaces of the beads at the end of stability study are taken as an indication of good stability $[19,20]$.

Probiotic functionality takes into account the ability of cells to resist gastrointestinal conditions and adhere to intestinal mucosa [4]. Thus, it is important that the encapsulation technique does not reduce viability and / or functionality. Both, spray drying (SD) and freeze drying (FD) can be used for manufacturing of probiotic powders on a large-scale [21, 22]. There are not many reports on encapsulation of the probiotic $B$. coagulans and its shelf life and therefore the present study was undertaken to encapsulate the probiotic $B$. coagulans. The encapsulated probiotic cells were dried using two different methods, spray drying (SD) and freeze drying (FD) and its impact on the shelf life was evaluated.

\section{MATERIAL AND METHODS}

The microbiological media and media ingredients were purchased from Himedia. The encapsulation materials were purchased locally.

\subsection{Bacterial cultures and maintenance \\ 2.1.1 Probiotic bacterium}

B. coagulans was a gift from a private Indian pharmaceutical company located at Hyderabad, India and it was maintained on GYEB medium [3]. The cells were grown in $50 \mathrm{ml}$ GYEB medium in $250 \mathrm{ml}$ Erlenmeyer flasks at $37^{\circ} \mathrm{C}$ on a rotary shaker at $150 \mathrm{rpm}$.

\subsubsection{Pathogenic strains}

Type strains, E.coli NCIM 1025 and S. typhi NCIM 1250 were cultured at $37^{\circ} \mathrm{C}$ on nutrient agar and brain heart infusion agar, respectively.

\subsection{Utilization of encapsulation material by probiotic strain and pathogens}

To GYEB medium without glucose equivalent amount of individual encapsulation material was added and $50 \mu \mathrm{l}$ of actively growing cultures $\left(\mathrm{OD}_{540}=0.1\right)$ were inoculated. After $24 \mathrm{~h}$ incubation at $37^{\circ} \mathrm{C}, 150 \mathrm{rpm}$ growth was checked by turbidity as well as by dilution plating.

\subsection{Production of biomass of probiotic cells}

Fed batch fermentation was carried out in a 6.61 bench top lab fermentor (Sartorius), to obtain the biomass required for encapsulation as described earlier [23]. Briefly, the process was carried out at $37^{\circ} \mathrm{C}$, with agitation range of $200-500 \mathrm{rpm}$ and aeration range of $0.75-1$ vvm to maintain the dissolved oxygen
(DO) between $30-70 \%$. Biomass was obtained by centrifuging the fermented broth at $7500 \mathrm{~g}$ for $10 \mathrm{~min}$ at $4^{\circ} \mathrm{C}$. The pellet was washed twice with phosphate buffered saline $(\mathrm{pH}$ 7.3) to remove spent medium and cellular wastes. A maximum yield of up to about $30 \mathrm{gl}^{-1} \mathrm{DCW}$ (Dry cell weight) as biomass was achieved. The cell pellet was dried in an oven at $70^{\circ} \mathrm{C}$ for about $30 \mathrm{~h}$ to obtain the cellular material to be encapsulated.

\subsection{Encapsulation conditions \\ 2.4.1 Spray drying}

Cellular material preparation (A): The dried biomass equivalent to $0.6-1.2 \times 10^{9} \mathrm{CFUg}^{-1}$ was transferred to a Falcon tube with $15 \mathrm{ml} \mathrm{DW}$ and left to hydrate for $30 \mathrm{~min}$ at RT. Encapsulation material preparation (B): Weighed amount of encapsulation material was added to $50 \mathrm{ml}$ of $\mathrm{DW}$ and homogenized for 15-20 min at approximately $1000 \mathrm{rpm}$ and left to hydrate for $30 \mathrm{~min}$ at RT under magnetic stirring. Only stable and homogenous encapsulation material preparations were used for encapsulation. Suspensions A and B were mixed thoroughly and the total volume was made up to $100 \mathrm{ml}$ with DW and this suspension was utilized for further processing. The suspension was analyzed for physical properties- refractive index (RI) and viscosity before proceeding with encapsulation. Efficiency of spray drying (SD) process is known to be influenced by the viscosity of the solution and solid content. Hence, RI and viscosity were determined using Abbe's refractometer and Brookfield 620 spindle viscometer as per the procedure recommended by the instrument manufacturers. The probiotic suspension was spray dried using JSIL bench top lab spray dryer (Bombay). Spray drying was performed at 3 different inlet temperatures $\left(110,120\right.$ and $\left.135^{\circ} \mathrm{C}\right)$ with fixed flow rate of $1.2 \mathrm{ml} \mathrm{min}^{-1}$ and compressor air pressure at $0.5 \mathrm{MPa}$. The spray dryer had no provision to control outlet temperature, which changed proportionally with air inlet temperature and feed flow rate conditions. The spray dried encapsulated probiotic formulations collected from the cyclone separator vessel were transferred to labeled sterile $10 \mathrm{ml}$ glass vials. The vials were incubated under 3 different sets of conditions, as stated in $\mathrm{ICH}$ guidelines, for accelerated stability studies: $4^{\circ} \mathrm{C}, 25^{\circ} \mathrm{C}(65 \% \mathrm{RH})$ and $40^{\circ} \mathrm{C}(75 \% \mathrm{RH})$.

\subsubsection{Cyclone recovery}

Cyclone recovery is an important attribute reflecting the efficiency of spray drying process. In a spray dryer the dried powder is separated from fine particles and collected in the cyclone container. The dry probiotic formulations were collected from the cyclone separator vessel on a clean butter paper and then quickly transferred into zip-lock pouches. Weight of the formulation recovered was recorded. Approximately $2 \mathrm{~g}$ of formulation was transferred to sterile glass vials, under aseptic conditions using a laminar air flow. Cyclone recovery (\%) was calculated using the expression [24].

$$
\% \text { cyclone recovery }=\frac{\text { Total solid }- \text { recovered solids }}{\text { Total solids }} \times 100
$$




\subsubsection{Freeze drying}

The cellular material and encapsulation material suspensions were prepared and mixed as described above for samples prepared for SD. The samples were stored at $4^{\circ} \mathrm{C}$. RI and viscosity of the samples were measured before subjecting them to freeze drying. The freeze drying process consisted of two cycles primary freezing and Secondary freezing. Primary freeze drying was carried out at $-40^{\circ} \mathrm{C}$ under vacuum where $92-93 \%$ of the moisture is usually removed [25]. Secondary freezing was continued for next $6 \mathrm{~h}$ to obtain the fully dried lyophilized probiotic powder.

\subsection{Viability assessment}

Encapsulation process efficiency was assessed in terms of CFU remaining after the process of SD or FD. The $\mathrm{CFUg}^{-1}$ before and after the drying process was estimated by using the standard technique of serial 10 -fold dilutions followed by plating on GYEA medium. The reduction in viability was calculated by the formula [26].

$$
\% \text { Reduction in viability }=(\mathrm{A}-\mathrm{B}) / \mathrm{A} \times 100
$$

where $\mathrm{A}$ and $\mathrm{B}$ are viable counts before and after the encapsulation process respectively.

\subsection{Stability studies}

As per the Q5-C ICH guidelines [27], samples were stored for 90 days, at $5^{\circ} \mathrm{C}$ (Refrigerator), and in a desiccator at $25^{\circ} \mathrm{C}$ having saturated solution of sodium nitrite to maintain $65 \%$ $\mathrm{RH}$ [28] and at $40^{\circ} \mathrm{C}$ in an environmental chamber with $75 \% \mathrm{RH}$. The samples were withdrawn for analysis on day $0,7,15,30,60$ and 90 .

The encapsulated formulations were analyzed for the following parameters to gauge the stability.

\subsubsection{Residual moisture content}

Residual moisture content was calculated using the following formula [29]

$$
\% \text { moisture }=\frac{\mathrm{Wf}-\mathrm{Wi}}{\mathrm{Wi}} \times 100
$$

Where $\mathrm{W}_{\mathrm{i}}$ and $\mathrm{W}_{\mathrm{f}}$ were the initial and final weights of the probiotic formulations.

\subsubsection{Water Activity $\left(a_{w}\right)$}

Water activity $\left(\mathrm{a}_{\mathrm{w}}\right)$ was measured using a water activity meter (Labswift-a $\mathrm{a}_{\mathrm{w}}$ Novasina, Switzerland) [30].

\subsubsection{Viability assessment}

The $\mathrm{CFUg}^{-1}$ after the drying process was estimated up to 90 days by using the standard technique of serial 10 -fold dilutions followed by plating on GYEA medium.

\subsubsection{Scanning electron microscopy (SEM)}

Encapsulated probiotic powders (day 0 and 90) were subjected to SEM for cell surface characterization [12]. The samples were examined under the scanning electron microscope model JEOL JSM-6380LA as per the recommended procedure of the manufacturer.

\section{RESULTS AND DISCUSSION}

\subsection{Utilization of encapsulation material for growth}

The probiotic $B$. coagulans and pathogenic strains $(E$. coli NCIM 1025 and $S$. typhi NCIM 1250) showed growth with all encapsulation material as the only $\mathrm{C}$ sources. Turbidity for $B$. coagulans was almost double as compared to pathogens. As can be seen from Table I, FOS and MD as the sole C source showed good growth for B. coagulans- $\left(1.4 \times 10^{9}\right.$ and $1.2 \times 10^{9} \mathrm{CFUg}^{-1}$, respectively). The overall utilization pattern for various encapsulation materials by the probiotic culture and the 2 pathogens was in the order of: $\mathrm{FOS}>\mathrm{MD}>\mathrm{SM}>\mathrm{XG}$. Corresponding cell counts for the media containing $\mathrm{XG}$ were lowest, possibly because of the structural complexity of this prebiotic that restricted its utilization [31].The results obtained may be extrapolated as the probiotic culture under evaluation could be able to propagate faster and colonize the GIT better than the harmful pathogenic bacteria.

\begin{tabular}{|c|c|c|c|c|c|c|}
\hline \multirow[b]{2}{*}{ EM } & \multicolumn{2}{|c|}{ B. coagulans } & \multicolumn{2}{|c|}{ E. coli NCIM 1025} & \multicolumn{2}{|c|}{ S. typhi NCIM 1250} \\
\hline & OD $\left(\mathbf{A}_{540 \mathrm{~nm}}\right)$ & $\begin{array}{l}\mathrm{CFUg}^{-1} \\
\left(\mathrm{x} 10^{9}\right)\end{array}$ & OD $\left(\mathbf{A}_{540 \mathrm{~nm}}\right)$ & $\begin{array}{c}\mathrm{CFUg}^{-1} \\
\left(\mathrm{x} 10^{9}\right)\end{array}$ & OD $\left(A_{540 \mathrm{~nm}}\right)$ & $\begin{array}{c}\mathrm{CFUg}^{-1} \\
\left(\mathrm{x} 10^{9}\right)\end{array}$ \\
\hline FOS & $0.8 \pm 0.3$ & $1.4 \pm 0.3$ & $0.4 \pm 0.11$ & $0.72 \pm 0.1$ & $0.2 \pm 0.05$ & $0.36 \pm 0.1$ \\
\hline MD & $0.7 \pm 0.2$ & $1.2 \pm 0.5$ & $0.3 \pm 0.10$ & $0.61 \pm 0.5$ & $0.1 \pm 0.0$ & $0.18 \pm 0.3$ \\
\hline SM & $0.6 \pm 0.1$ & $1.1 \pm 0.8$ & $0.3 \pm 0.12$ & $0.63 \pm 0.2$ & $0.2 \pm 0.05$ & $0.37 \pm 0.2$ \\
\hline $\mathrm{XG}$ & $0.5 \pm 0.1$ & $0.8 \pm 0.2$ & $0.2 \pm 0.05$ & $0.58 \pm 0.3$ & $0.2 \pm 0.05$ & $0.4 \pm 0.3$ \\
\hline
\end{tabular}

Table I: EM utilization profile of probiotic and pathogenic strains.

Key :- EM: Encapsulation material

\subsection{Assessment of viability}

Biomass was estimated as CFU before and after the encapsulation. Higher reduction in viability is a reflection of less protecting ability of the encapsulation material and is also an indication of harshness of the drying process employed. Table II shows the optimized process parameters and viability data for SD and FD processes.

As may be noted from the table, the reduction in viability of SD and FD samples was in the order: SM (19\% v/s 4\%) <FOS $(27 \% \mathrm{v} / \mathrm{s} 7.2 \%)<\mathrm{MD}(32 \% \mathrm{v} / \mathrm{s} 12.3 \%)<\mathrm{XG}(40 \% \mathrm{v} / \mathrm{s} 27.5 \%)$ The viability loss in FD process $(4-27.5 \%)$ was much lower than loss incurred in the SD process (19-40\%). Thus, FD was milder method of drying for $B$. coagulans. Since, minimum loss of viability occurred for SM coated cells, it was considered to be the best encapsulation material for B. coagulans, while XG was the least effective one. The ability of encapsulation material to protect the cellular material from the harsh conditions of drying is crucial for the product viability and stability. Samples containing 20-30\% solids had relatively low viscosity $(80-100 \mathrm{cp})$ resulting in better SD efficiency $(19-40 \%$ loss in viability) at the optimum temperature as shown in the Table II. 
Table II: Process parameters for SD and FD and viability of probiotic samples.

\begin{tabular}{|c|c|c|c|c|}
\hline Samples & SM & FOS & MD & XG \\
\hline \multicolumn{5}{|c|}{ Process parameters for SD } \\
\hline Inlet Temperature & $110^{\circ} \mathrm{C}$ & $135^{\circ} \mathrm{C}$ & $135^{\circ} \mathrm{C}$ & $120^{\circ} \mathrm{C}$ \\
\hline Flow rate & & & & \\
\hline Total solid content $\left(\right.$ g 100ml $\left.^{-1}\right)$ & 30 & 25 & 30 & 20 \\
\hline EM: CM & $4: 1$ & $3: 1$ & $7: 3$ & $19: 1$ \\
\hline Viscosity & $80 \mathrm{cp}$ & $100 \mathrm{cp}$ & $100 \mathrm{cp}$ & $90 \mathrm{cp}$ \\
\hline \multicolumn{5}{|c|}{ Viability } \\
\hline$\overline{\mathrm{CFUg}}^{-1}$ before spray drying (A) & $0.62 \times 10^{9}$ & $0.98 \times 10^{9}$ & $0.73 \times 10^{9}$ & $1.2 \times 10^{9}$ \\
\hline $\mathrm{CFU} \mathrm{g}^{-1}$ after spray drying (B) & $0.5 \times 10^{9}$ & $0.72 \times 10^{9}$ & $0.5 \times 10^{9}$ & $0.72 \times 10^{9}$ \\
\hline$\%$ reduction in viability & 19 & 27 & 32 & 40 \\
\hline \multicolumn{5}{|c|}{ Process parameters for FD } \\
\hline Total solid content & 60 & 50 & 60 & 40 \\
\hline EM: CM & $4: 1$ & $3: 1$ & $7: 3$ & 19:1 \\
\hline \multicolumn{5}{|c|}{ Viability } \\
\hline$\overline{\mathrm{CFU}} \mathrm{g}^{-1}$ before freeze drying (A) & $0.62 \times 10^{9}$ & $0.98 \times 10^{9}$ & $0.73 \times 10^{9}$ & $1.2 \times 10^{9}$ \\
\hline CFU g ${ }^{-1}$ after freeze drying (B) & $0.6 \times 10^{9}$ & $0.91 \times 10^{9}$ & $0.64 \times 10^{9}$ & $0.87 \times 10^{9}$ \\
\hline$\%$ reduction in viability & 4 & 7.2 & 12.3 & 27.5 \\
\hline
\end{tabular}

Key: - EM: Encapsulation material

CM: Cellular material

Though FOS and MD encapsulated samples were subjected to higher temperature of $135^{\circ} \mathrm{C}$, the viability loss was lower than $\mathrm{XG}$ encapsulated biomass at $120^{\circ} \mathrm{C}$. SM was spray dried at $110^{\circ} \mathrm{C}$ since it had a risk of charring at temperature above $120^{\circ} \mathrm{C}$. Irrespective of the drying method, protective abilities of different encapsulation materials were in the order: SM> FOS $>M D>X G$. Survival was maximum for SM $(80 \%)$ and minimum for $\mathrm{XG}(60 \%)$ coated cells.

\subsection{Cyclone recovery}

Generally, the combination of high temperature and low feed resulted in low particle stickiness and hence higher cyclone recoveries. Table III shows cyclone recovery of different samples after SD. FOS and MD samples which were spray dried at $135^{\circ} \mathrm{C}$ showed higher cyclone recoveries of $48 \%$ and $56 \%$ respectively. While, SM and XG encapsulated probiotics which were spray dried at 110 and $120^{\circ} \mathrm{C}$ resulted in lesser cyclone recovery of 46 and $40 \%$ recovery.

Table III: Cyclone recovery after spray dried encapsulated probiotic $B$. coagulans.

\begin{tabular}{ccccc}
\hline EM & $\begin{array}{c}\text { Solid } \\
\text { content } \\
(\boldsymbol{\%})\end{array}$ & $\begin{array}{c}\text { Total solid } \\
\text { content } \\
(\mathbf{E M + C M})(\mathbf{g})\end{array}$ & $\begin{array}{c}\text { Recovered solids } \\
\text { (encapsulated } \\
\text { powder) }(\mathbf{g})\end{array}$ & $\begin{array}{c}\text { Cyclone } \\
\text { recover } \\
\mathbf{y}(\boldsymbol{\%})\end{array}$ \\
\hline SM & 30 & 60 & 28 & 46 \\
FOS & 25 & 50 & 24 & 48 \\
MD & 30 & 60 & 34 & 56 \\
XG & 20 & 40 & 16 & 40 \\
\hline
\end{tabular}

Key: - EM: Encapsulation material

CM: Cellular material

The amount of the dried product recovered via cyclone separation is influenced by many parameters, such as drying air flow, local velocities, the spatial geometry of the separator and the adhesiveness and cohesiveness of the particles while interacting with the drying chamber [32]. At higher temperatures the evaporation of water (i.e. drying) is faster and tendency of samples to stick to the drying chamber is very less [12]. Hence, recovery in the cyclone separator was higher for MD and FOS, as against the recoveries for $\mathrm{SM}$ and $\mathrm{XG}$.

\subsection{Stability studies on the optimized final product 3.5.1 Residual moisture content and Water activity $\left(a_{w}\right)$ :}

Figure I depicts the trend of residual moisture content and $\mathrm{a}_{\mathrm{w}}$ for the spray dried products. Residual moisture content is represented by the line graph. Residual moisture content of samples ranged between 3.8 to $5.5 \%$ during the storage tenure. With increase in storage temperature, the residual moisture content also increased but it remained below 5.5\%. Thus, the residual moisture content in all the spray dried samples was within the recommended limit of under $5.5 \%$ as per the ICH guidelines.

The $a_{w}$ values are represented as bar graph. For FOS-SD samples stored at $5^{\circ} \mathrm{C}, \mathrm{a}_{\mathrm{w}}$ of was almost the same throughout storage period. With rise in temperature, an increase in $\mathrm{a}_{\mathrm{w}}$ was indicative of the negative effect of temperature on water activity and thus product stability. In our study, $\mathrm{a}_{\mathrm{w}}$ remained below 0.6 , within the recommended limits [27] and therefore the product can be considered as stable. Residual moisture content and $\mathrm{a}_{\mathrm{w}}$ values for MD encapsulated spray dried samples were higher than those of FOS encapsulated spray dried samples. Both the parameters did not show any proportional increase with rise in storage temperature and $\mathrm{RH}$ conditions. Stability of samples prepared with SM and spray dried was in the order: $5^{\circ} \mathrm{C}>25^{\circ} \mathrm{C}(65 \% \mathrm{RH})>40^{\circ} \mathrm{C}$ (75\% RH). Corresponding $\mathrm{a}_{\mathrm{w}}$ values were all within 0.6 . For $40^{\circ} \mathrm{C}$ with $75 \% \mathrm{RH}$, residual moisture content was somewhat higher $(5.2 \%)$ but still within the permissible limit. This could be because of the higher water binding property of SM compared to other encapsulation material [33]. Water activity of the samples prepared with XG and spray dried was stable during 90 days storage but residual moisture content exceeded the recommended limit of $5.5 \%$ indicating some instability of the formulation. Also XG was not an effective barrier to protect the cells from elevated storage conditions. Similar findings have also been reported in the literature [34]. 

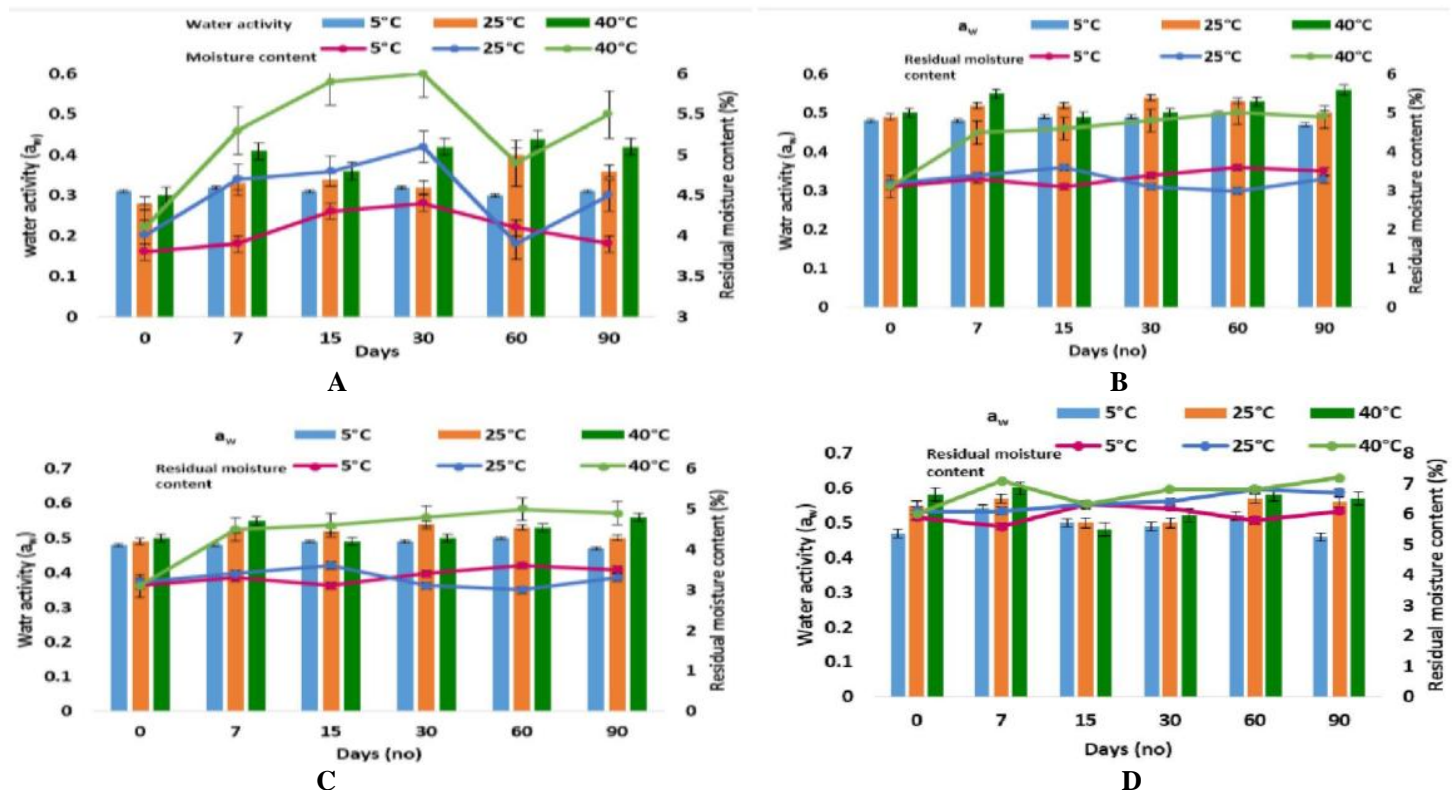

Fig. I: Water activity (aw) and residual moisture content of spray dried probiotic preparations of B. Coagulans using a) FOS, b) MD, c) SM and d) XG.
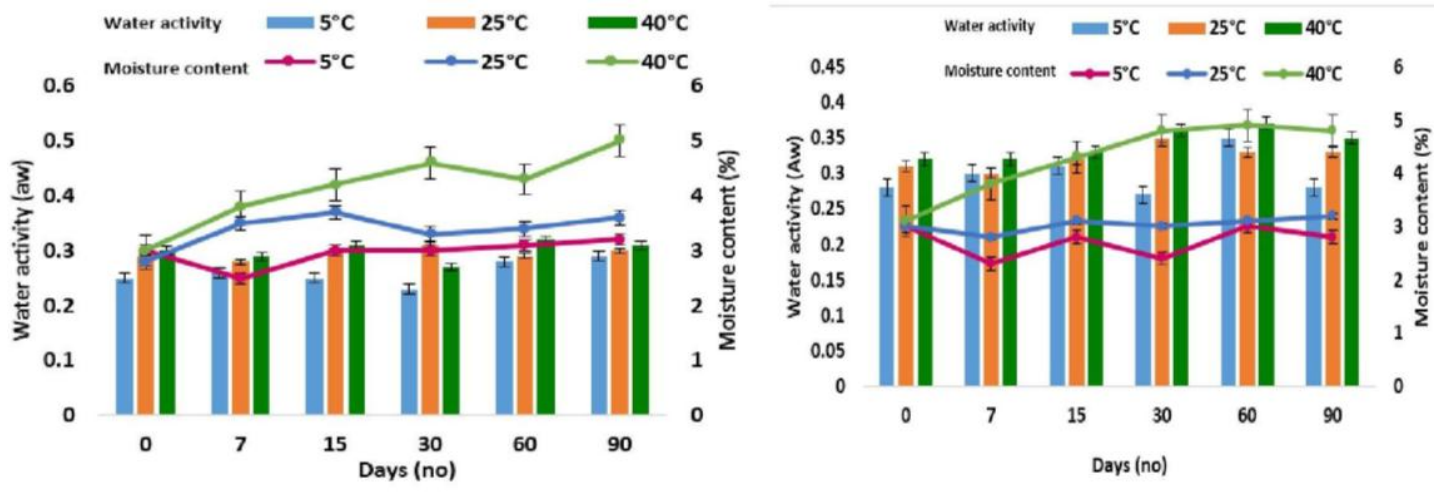

A

B
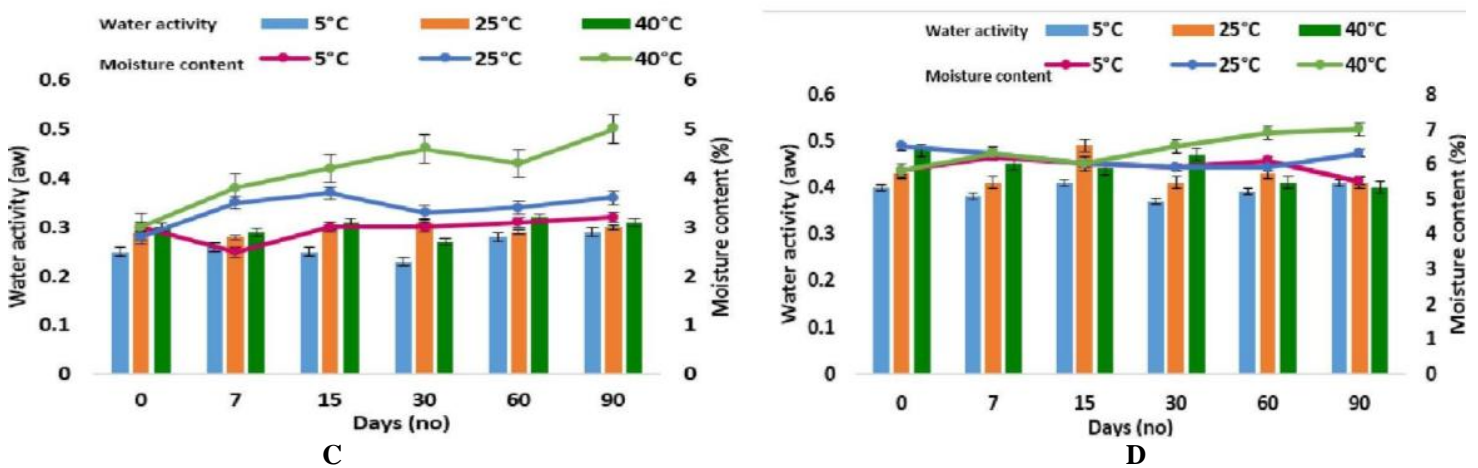

Fig. II: Water activity (aw) and residual moisture content of freeze dried cells of encapsulated probiotic B. Coagulans using a) FOS, b) MD, c) SM and d) XG.

For samples showing lower $\mathrm{a}_{\mathrm{w}}$, the RI at the time of encapsulation was between $1.33-1.371$, very close to RI of pure water [21]. Therefore, the samples were rather free flowing due to low viscosity and spray drying efficiency was expected to be better [35].Reduced $a_{w}$ also minimizes other undesirable chemical changes occurring during storage [36].

Figure II displays residual moisture content and $a_{w}$ (bar graph) values for freeze dried probiotic samples encapsulated using the 4 encapsulation materials. The $\mathrm{a}_{\mathrm{w}}$ values on day 0 and 90, for FOS-FD samples stored at $5^{\circ} \mathrm{C}$, were almost unchanged indicating their inertness. Residual moisture content trend was also stable for $5^{\circ} \mathrm{C}$ samples. At temperatures $25^{\circ} \mathrm{C}(65 \% \mathrm{RH})$ and $40^{\circ} \mathrm{C}$ (75\% RH) the samples displayed non-linear increments in $\mathrm{a}_{\mathrm{w}}$ as well as residual moisture values, possibly indicating some product degradation. Maximum residual moisture and $\mathrm{a}_{\mathrm{w}}$ readings for MDFD samples were $4.8 \%$ and 0.38 respectively. The MD -FD 
samples under all the conditions were found to be stable throughout the storage period. Similar results were obtained for SM-FD samples where the stability of formulations was in the order: $5^{\circ} \mathrm{C}>25^{\circ} \mathrm{C}(65 \% \mathrm{RH})>40^{\circ} \mathrm{C}(75 \% \mathrm{RH}) . \mathrm{a}_{\mathrm{w}}$ values of XGFD samples were within 0.6 but residual moisture content had crossed $7 \%$ (higher than recommended value of $5.5 \%$ ). This could be detrimental to the product viability and thus quality.

\subsubsection{Viability}

Loss of viability in non-encapsulated cells was faster and continued till the $90^{\text {th }}$ day of storage as was anticipated (Figure III). Rate of loss of viability was lesser at $5^{\circ} \mathrm{C}$, higher at $25^{\circ} \mathrm{C}$ (65\% RH) and highest at $40^{\circ} \mathrm{C}(75 \% \mathrm{RH})$. The $\mathrm{CFU}$ count of samples stored at $40^{\circ} \mathrm{C}(75 \% \mathrm{RH})$ was reduced to less than half of the initial value $\left(0.38 \times 10^{9} \mathrm{CFUg}^{-1}\right)$, by 90 days. These results show that the rise in temperature coupled with humid environment initiated the bacterial metabolism and hence process of degradation and loss in viability was accelerated [37,38].

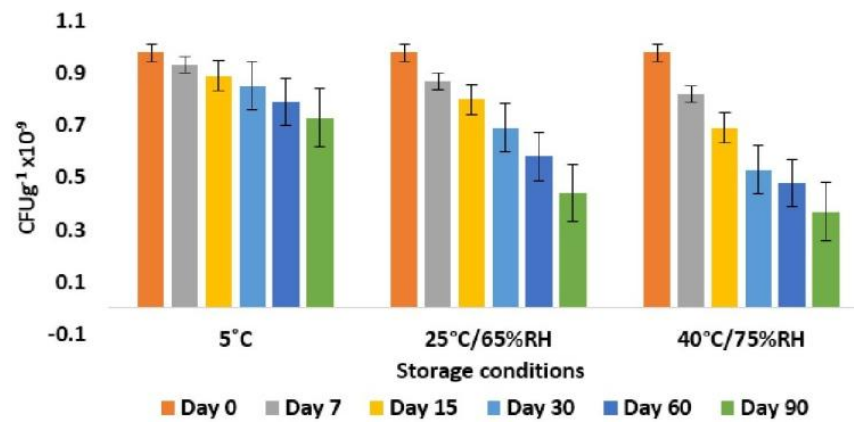

Fig. III: Viability profile of non-encapsulated probiotic B. coagulans.

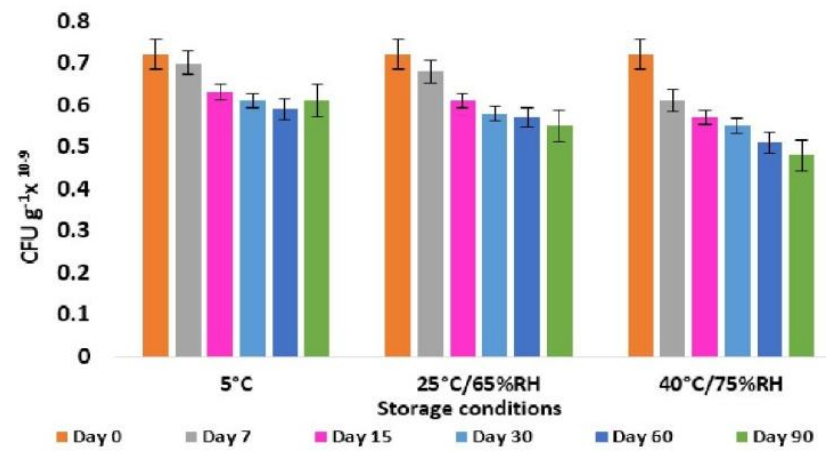

(A)

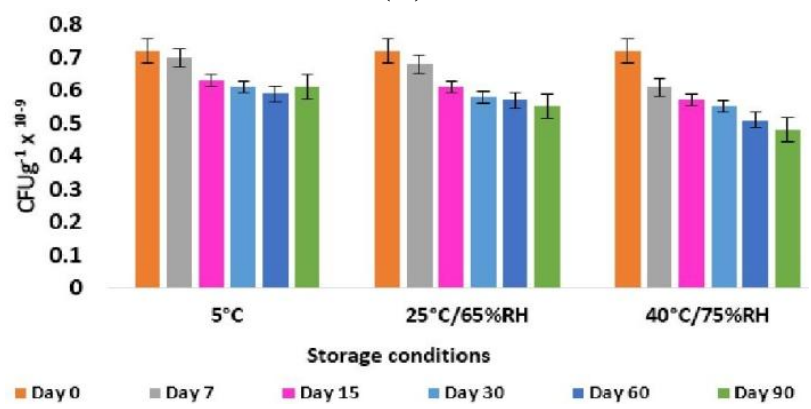

(B)

Fig. IV: Viability profile of a) FOS-SD and b) FOS-FD encapsulated cells of probiotic B. Coagulans.

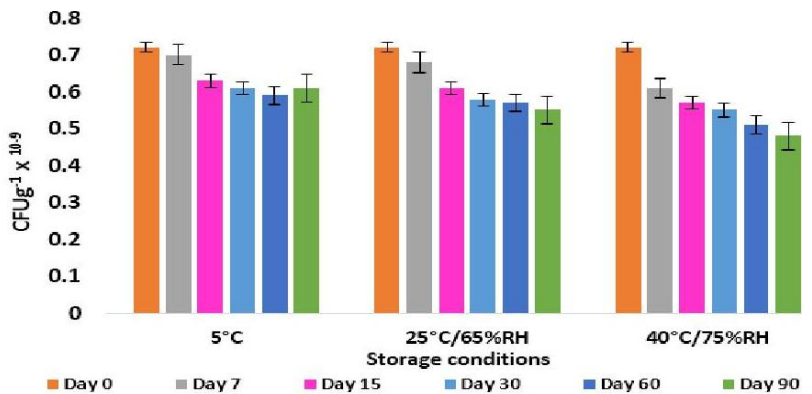

(A)

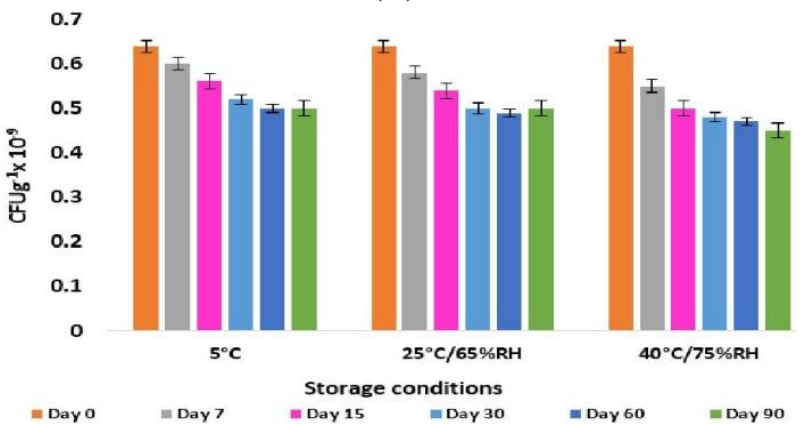

(B)

Fig. V: Viability profile of a) MD-SD and b) MD-FD samples of probiotic B. coagulans.

Figure IV presents the viability $\left(\mathrm{CFUg}^{-1}\right)$ of probiotics encapsulated with FOS. As seen from the figure, viability decreased during the 90 days span from $0.72 \times 10^{9}$ (day 0) to $0.48 \times 10^{9}$ (day 90) for samples stored at $40^{\circ} \mathrm{C}(75 \% \mathrm{RH})$. The drop in cell count was rapid and high in the first 15 days of storage. Further loss in viability was slow, thus storage in air tight glass vials helped in extending the shelf life of the formulations. Cell counts of FOS-FD samples also decreased with increase in storage temperature. The lowest counts recorded for FOS-SD and FOS-FD samples at $40^{\circ} \mathrm{C}(75 \%$ RH) were 38 and $70 \%$ respectively.

Viability profiles of MD-SD and MD-FD samples are represented in Figure V. MD-SD sample showed the decline in cell counts from $0.5 \times 10^{9}$ (day 0) to $0.31 \times 10^{9}$ (day 90) representing 32\% reduction. Cell counts for MD-FD samples dropped from $0.64 \times 10^{9}$ (day 0$)$ to $0.46 \times 10^{9}$ (day 90$)$ i.e. $12.3 \%$ loss in viability.

Figure VI displays the viability profile recorded for probiotic cells encapsulated using SM. Cell counts at $40^{\circ} \mathrm{C}(75 \%$ $\mathrm{RH})$ for SD and FD samples were $54 \%$ and $68 \%$ respectively. As is evident, FD method was milder than SD and hence viable counts were higher.

Finally, Figure VII represents the viability of cells encapsulated with XG, spray dried and freeze dried. As seen in the figure, for samples stored at $40^{\circ} \mathrm{C}(75 \% \mathrm{RH})$ for SD samples, the viability decreased during the span of 90 days from $0.72 \times 10^{9}$ to $0.45 \times 10^{9}$ equivalent to $37.5 \%$ loss. The drop in cell count was rapid and high in the first 15 days. Similar was the profile for FD samples stored at $40^{\circ} \mathrm{C}(75 \% \mathrm{RH})$ where cell counts declined from $1.2 \times 10^{9}$ to $0.87 \times 10^{9}$ equivalent to a viability loss of $27.5 \%$. 


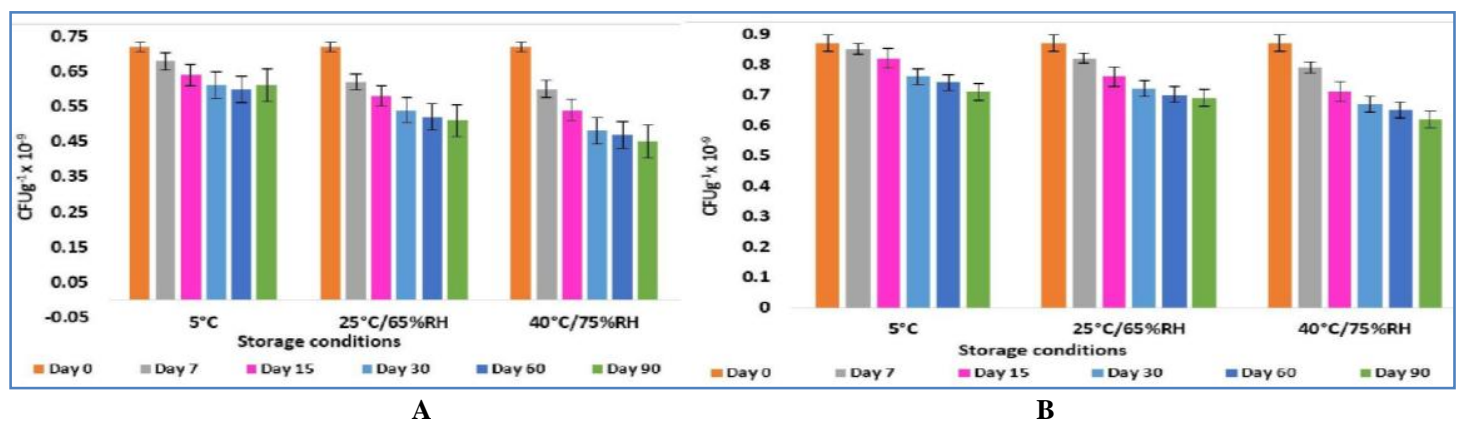

Fig. VI: Viability profile of a) SM-SD and b) SM-FD samples of probiotic B. coagulans.

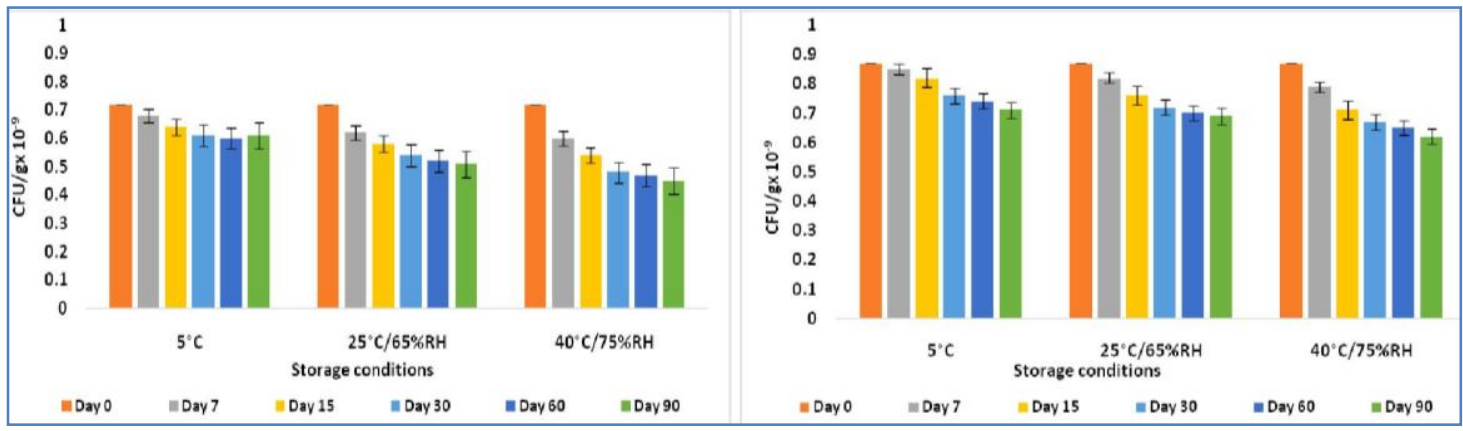

Fig. VII: Scanning electron micrograph of MD encapsulated B. coagulans cells on a) day 0 and b) day 90 .

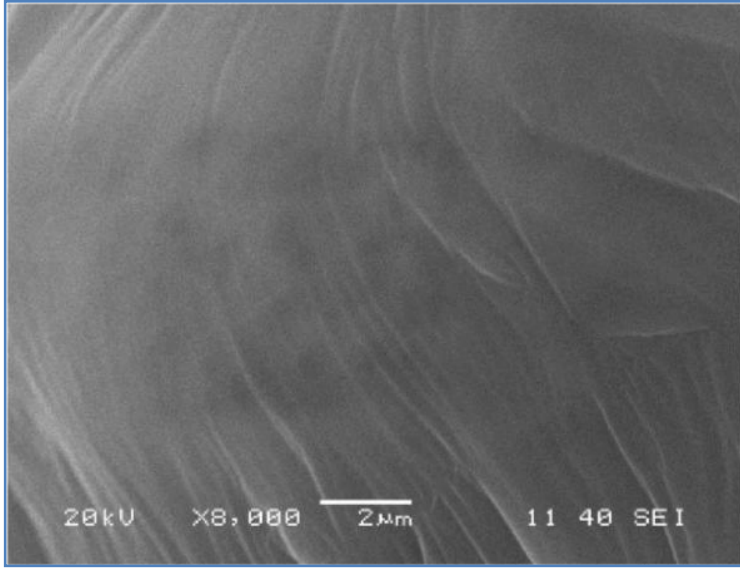

A

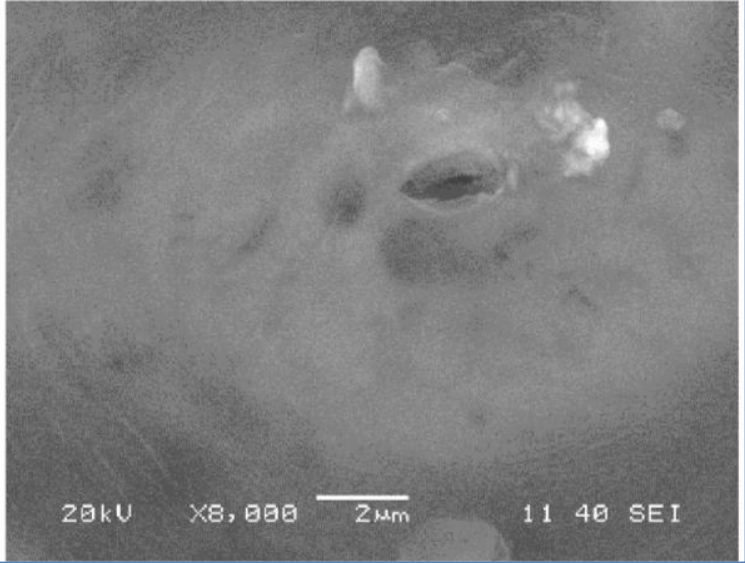

B

Fig. VII: Viability profile of a) XG-SD and b) XG-FD samples of probiotic B. coagulans.

\subsubsection{Evaluation of encapsulated formulations using SEM}

It is known that the morphology of the beads prepared with encapsulation of biomass varies based on the coating material used and drying conditions employed [39]. The particulate structure of the encapsulated product can be viewed using SEM [19]. The scanning revealed that both the drying procedures (SD and FD) had resulted in partially collapsed particles with the appearance of deflated ball like spherical structures. Day 0 samples appeared smooth due to the even spreadability of encapsulation material. During the course of storage, the encapsulation material as well as probiotic cells might have come in contact with the moisture and oxygen present in the glass vial and integrity may have got compromised due to hygroscopicity of encapsulation material and/or growth of cells, resulting in formation of some roughness on surface of particles. The loss of integrity of outer surface increases the surface area for interactions with the environment and may negatively affect the stability of the product. A representative electron micrograph for the particle surfaces where probiotic cultures encapsulated with MD were spray dried is shown in Figure VIII.

As may be noted from the electron micrograph, the external surface of the day 0 sample was smooth spherical and non-porous, indicating the inertness of the product (Figure VIIIa). The smoother the surface, the lesser or no interaction pockets for oxygen, humidity etc. and thus more stable is the formulation. Allan-Wojtas and colleagues have reported that they could effectively see the morphological difference in the empty and bacteria loaded calcium alginate microcapsules [19].

Exposure of microorganisms to stress conditions decreases their viability in any product. In fact, several researchers have demonstrated that numerous probiotic food products including traditional fermented dairy products, have failed to meet 
the requirement of minimal level of viable bacteria [40-42]. Viability of probiotic cells in food products and their activity at the target site depends on various factors like conditions during fermentation, downstream processing, storage as well as the conditions prevailing during passage through gastrointestinal tract $[29,43]$.

The traditional spray dried probiotic products containing Lactobacillus strains have shown $15-40 \%$ viability which can be considered as less than desirable [44]. In our study, the $B$. coagulans could withstand the spray drying conditions better showing 60-80\% viability (Table II). This can be partly attributed to better spore forming ability of our $B$. coagulans probiotic strain. It is known that spores are able to withstand harsh environmental conditions [45]. The improved survival can also be due to choice of suitable encapsulation material and tightly controlled conditons during spray drying and freeze drying. A study done by Kearney et al. has demonstrated the importance of spray drying conditions for maintaining the viability of probiotic yoghurt containing Lactobacillus paracasei NFBC 338 [39].

Our results confirm that the process of spray drying is harsher than the freeze drying. The viability of bacterial population drops drastically at high temperatures and dehydration conditions during the SD process as against the freeze drying process $[9,46,47]$. Loss of viability is principally caused by cytoplasmic membrane damage although the cell wall, ribosome and DNA are also affected at higher temperatures [9, 46, 48, 49]. The stationary phase cultures are more resistant to heat compared to cells in exponential growth phase [12]. Our best results, viability of $96 \%$ and $81 \%$ for FD and SD samples respectively, with SM as encapsulating material is largely in agreement with previous reported results by others. It was shown that a rifampicin resistant variant of Lactobacillus paracasei NFBC 338, showed survival rate of $>80 \%$ during spray-drying in reconstituted skimmed milk, at $100-110^{\circ} \mathrm{C}$ [50], while under similar conditions, a survival rate of $>60 \%$ for L. rhamnosus GG has also been reported [51]. In another study $B$. coagulans cells were spray dried with calcium alginate and the loss of viability was restricted to $30 \%$ [47]. These reports also highlight the fact that survival of cells varies depending on the species under investigation. Though freeze drying results in lesser loss in viability and frozen cultures occupy less volume and require less storage space at sub-zero temperatures, the cost of cooling is prohibitively high for freeze drying and hence spray drying may still be preferred as the SD process is 5-10 times cheaper than FD process [52].

\section{CONCLUSION}

The encapsulated formulations showed a significant drop in viability only during the first 15 days of storage. This confirmed the fact that irrespective of the encapsulation material used, encapsulation was able to slow down the cell death. With spray drying as well as freeze drying the least loss in viability was seen with skimmed milk as encapsulation medium. The process of freeze drying resulted in milder drying conditions than the spray drying. It was concluded that amongst the 4 encapsulation materials evaluated, skimmed milk was the most effective agent. The work described here contributes to the better understanding of the encapsulation process for the probiotic B. coagulans as very few reports are available on choice of encapsulating materials for this probiotic. Also data obtained with scanning electron microscopy supports the work by other researchers to develop it as a useful, independent tool for studying the integrity of particle surface of encapsulated microbial cells.

\section{ACKNOWLEDGMENT}

We wish to acknowledge the help provided by Institute of Chemical Technology, Matunga, Mumbai, India for spray drying and SEM analysis of encapsulated formulations.

\section{Financial support and sponsorship: Nil.}

Conflict of Interests: There are no conflicts of interest.

\section{REFERENCES}

1. Joint, F. A. O. WHO Working Group on Drafting Guidelines for the Evaluation of Probiotics in Food. Guidelines for the evaluation of probiotics in food: report of a Joint FAO/WHO Working Group on Drafting Guidelines for the Evaluation of Probiotics in Food, London, Ontario, Canada. 2007. April 30 and May 1, 2002. ftp.fao.org/es/esn/food/wgreport2.pdf.

2. Harish K, Varghese T. Probiotics in humans-evidence based review. Calicut Medical Journal. 2006; 4(4):3113-3117.

3. Pandey KR, Naik SR, Vakil BV. Probiotics, prebiotics and synbiotics-a review. Journal of food science and technology. 2015; 52(12):7577-87.

4. Ross RP, Desmond C, Fitzgerald GF, Stanton C. Overcoming the technological hurdles in the development of probiotic foods. Journal of Applied Microbiology. 2005; 98(6):1410-1417.

5. Weinbreck F, Bodnár I, Marco ML. Can encapsulation lengthen the shelflife of probiotic bacteria in dry products? International journal of food microbiology. 2010; 136(3):364-367.

6. Tamime AY, Marshall VM, Robinson RK. Microbiological and technological aspects of milks fermented by bifidobacteria. Journal of Dairy Research. 1995; 62(01):151-187.

7. Dave RI, Shah NP. Effect of cysteine on the viability of yoghurt and probiotic bacteria in yoghurts made with commercial starter cultures. International Dairy Journal. 1997; 7(8-9):537-545.

8. Vidhyalakshmi R, Bhakyaraj R, Subhasree RS. Encapsulation "the future of probiotics"-a review. Advances in Biological Research. 2009; 3(34):96-103.

9. Meng XC, Stanton C, Fitzgerald GF, Daly C, Ross RP. Anhydrobiotics: The challenges of drying probiotic cultures. Food Chemistry. 2008; 106(4):1406-1416.

10. Cha BK, Jung SM, Choi CH, Song ID, Lee HW, Kim HJ, Hyuk J, Chang SK, Kim K, Chung WS, Seo JG. The effect of a multispecies probiotic mixture on the symptoms and fecal microbiota in diarrhea-dominant irritable bowel syndrome: a randomized, double-blind, placebo-controlled trial. Journal of clinical gastroenterology. 2012; 46(3):220-227.

11. Hernández-Carranza P, López-Malo A, Jiménez-Munguía MT Microencapsulation quality and efficiency of Lactobacillus casei by spray drying using maltodextrin and vegetable extracts. Journal of Food Research. 2014; 3(1):61-68.

12. Behboudi-Jobbehdar S, Soukoulis C, Yonekura L, Fisk I. Optimization of spray-drying process conditions for the production of maximally viable microencapsulated L. acidophilus NCIMB 701748. Drying Technology. 2013; 31(11):1274-1283.

13. Annan NT, Borza AD, Hansen LT. Encapsulation in alginate-coated gelatin microspheres improves survival of the probiotic Bifidobacterium adolescentis 15703T during exposure to simulated gastro-intestinal conditions. Food Research International. 2008; 41(2):184-193.

14. Shahidi F, Han XQ. Encapsulation of food ingredients. Critical Reviews in Food Science \& Nutrition. 1993; 33(6):501-547. 
15. Jackson LS, Lee K. Microencapsulation and the food industry. Lebensmittel-Wissenschaft+ Technologie. 1991; 24(4):289-97.

16. Talwalkar A, Kailasapathy K. Effect of microencapsulation on oxygen toxicity in probiotic bacteria. Australian Journal of Dairy Technology. 2003; 58(1):36.

17. Champagne CP, Fustier P. Microencapsulation for the improved delivery of bioactive compounds into foods. Current opinion in biotechnology. 2007; 18(2):184-90

18. Chen MJ, Chen KN. Applications of probiotic encapsulation in dairy products. Encapsulation and controlled release technologies in food systems. 2007; 15(4):83-112.

19. Allan-Wojtas P, Hansen LT, Paulson AT. Microstructural studies of probiotic bacteria-loaded alginate microcapsules using standard electron microscopy techniques and anhydrous fixation. LWT-Food Science and Technology. 2008; 41(1):101-8.

20. Mokarram RR, Mortazavi SA, Najafi MH, Shahidi F. The influence of multi stage alginate coating on survivability of potential probiotic bacteria in simulated gastric and intestinal juice. Food Research International. 2009; 42(8):1040-1045.

21. Ying D, Sun J, Sanguansri L, Weerakkody R, Augustin MA. Enhanced survival of spray-dried microencapsulated Lactobacillus rhamnosus GG in the pr*esence of glucose. Journal of Food Engineering. 2012; 109(3):597-602.

22. Del Piano M, Strozzi P, Barba M, Allesina S, Deidda F, Lorenzini P, Morelli L, Carmagnola S, Pagliarulo M, Balzarini M, Ballarè M. In vitro sensitivity of probiotics to human pancreatic juice. Journal of clinical gastroenterology. 2008; 42:S170-3.

23. Pandey KR and Vakil BV. Development of bioprocess for high density cultivation yield of the probiotic Bacillus coagulans and its spores. Journal of BioScience \& Biotechnology. 2016; 5(2):173-181.

24. Adhikari B, Howes T, Bhandari BR, Langrish TA. Effect of addition of proteins on the production of amorphous sucrose powder through spray drying. Journal of Food Engineering. 2009; 94(2):144-153.

25. Nireesha GR, Divya L, Sowmya C, Venkateshan N, Babu MN, Lavakumar V. Lyophilization/freeze drying - an review. International journal of novel trends in pharmaceutical sciences. 2013; 3(4):87-98.

26. Ding $\mathrm{W}$ and Shah N. Effect of various encapsulating materials on the stability of probiotic bacteria. Journal of Food Science. 2009; 74(2):M100-M107.

27. Guideline, I. H. T. (1995). Quality of Biotechnological Products: Stability Testing of Biotechnological. Biological Products Q5C.

28. Rockland LB. Saturated salt solutions for static control of relative humidity between $5^{\circ}$ and $40^{\circ}$ C. Analytical Chemistry. 1960; 32(10):1375-1376.

29. Quinton LA, Kennedy JF. American Association of Cereal Chemists Approved Methods, CD-ROM: American Association of Cereal Chemists, 2000, ISBN: 1-891127-13-6.

30. Kurtmann L, Carlsen CU, Risbo J and Skibsted LH. Storage stability of freeze-dried Lactobacillus acidophilus (La-5) in relation to water activity and presence of oxygen and ascorbate. Cryobiology. 2009; 58(2):175180 .

31. Dogan M, Toker OS, Aktar T, Goksel M. Optimization of gum combination in prebiotic instant hot chocolate beverage model system in terms of rheological aspect: mixture design approach. Food and Bioprocess Technology. 2013; 6(3):783-94.

32. Lian WC, Hsiao HC, Chou CC. Survival of bifidobacteria after spraydrying. International journal of food microbiology. 2002; 74(1):79-86.

33. Desai AR, Powell IB, Shah NP. Survival and activity of probiotic lactobacilli in skimmed milk containing prebiotics. Journal of Food Science. 2004; 69(3):FMS57-FMS60

34. Nazzaro F, Fratianni F, Coppola R, Sada A, Orlando P. Fermentative ability of alginate-prebiotic encapsulated Lactobacillus acidophilus and survival under simulated gastrointestinal conditions. Journal of Functional Foods. 2009; 1(3):319-23.

35. Peighambardoust SH, Tafti AG, Hesari J. Application of spray drying for preservation of lactic acid starter cultures: a review. Trends in Food Science \& Technology. 2011; 22(5):215-24.
36. Desmond C, Ross RP, O'callaghan E, Fitzgerald G, Stanton C. Improved survival of Lactobacillus paracasei NFBC 338 in spray-dried powders containing gum acacia. Journal of applied microbiology. 2002 93(6):1003-11.

37. Shiah FK, Ducklow HW. Bacterioplankton growth responses to temperature and chlorophyll variations in estuaries measured by thymidine: leucine incorporation ratio. Aquatic Microbial Ecology. 1997; 13(2):151-159.

38. Price PB, Sowers T. Temperature dependence of metabolic rates for microbial growth, maintenance, and survival. Proceedings of the National Academy of Sciences of the United States of America. 2004; 101(13):4631-4636

39. Kearney N, Meng XC, Stanton C, Kelly J, Fitzgerald GF, Ross RP. Development of a spray dried probiotic yoghurt containing Lactobacillus paracasei NFBC 338. International Dairy Journal. 2009; 19(11):684-9.

40. Shah NP. Probiotic bacteria: selective enumeration and survival in dairy foods. Journal of dairy science. 2000; 83(4):894-907.

41. Lourens-Hattingh A, Viljoen BC. Yogurt as probiotic carrier food. International dairy journal. 2001; 11(1):1-7.

42. Masco L, Huys G, De Brandt E, Temmerman R, Swings J. Culturedependent and culture-independent qualitative analysis of probiotic products claimed to contain bifidobacteria. International journal of food microbiology. 2005; 102(2):221-30.

43. Gbassi GK, Vandamme T. Probiotic encapsulation technology: from microencapsulation to release into the gut. Pharmaceutics. 2012; 4(1):149-63.

44. Dianawati D, Mishra V, Shah NP. Survival of Bifidobacterium longum 1941 microencapsulated with proteins and sugars after freezing and freeze drying. Food research international. 2013; 51(2):503-9.

45. Hong HA, Cutting SM. The use of bacterial spore formers as probiotics. FEMS microbiology reviews. 2005; 29(4):813-35.

46. Gardiner GE, O'sullivan E, Kelly J, Auty MA, Fitzgerald GF, Collins JK, Ross RP, Stanton C. Comparative survival rates of human-derived probiotic Lactobacillus paracasei and Lactobacillus salivarius strains during heat treatment and spray drying. Applied and environmental microbiology. 2000; 66(6):2605-12.

47. Yadav N, Morris G, Harding SE, Ang S, Adams GG. Various noninjectable delivery systems for the treatment of diabetes mellitus. Endocrine, Metabolic \& Immune Disorders-Drug Targets (Formerly Current Drug Targets-Immune, Endocrine \& Metabolic Disorders). 2009; 9(1):1-3.

48. Mattila-Sandholm T, Myllärinen P, Crittenden R, Mogensen G, Fondén $\mathrm{R}$, Saarela M. Technological challenges for future probiotic foods International Dairy Journal. 2002; 12(2):173-82.

49. Corcoran BM, Ross RP, Fitzgerald GF, Stanton C. Comparative survival of probiotic lactobacilli spray-dried in the presence of prebiotic substances. Journal of Applied Microbiology. 2004; 96(5):1024-39.

50. Burgain J, Gaiani C, Linder M, Scher J. Encapsulation of probiotic living cells: From laboratory scale to industrial applications. Journal of Food Engineering. 2011; 104(4):467-83.

51. Oluwaseun Sunny-Roberts E, Knorr D. Cellular injuries on spray-dried Lactobacillus rhamnosus GG and its stability during food storage. Nutrition \& Food Science. 2011; 41(3):191-200.

52. To B, Etzel MR. Spray drying, freeze drying, or freezing of three different lactic acid bacteria species. Journal of Food Science. 1997; 62(3):576-8.

\section{How to cite this article:}

Pandey KR, Vakil BV. Encapsulation of Probiotic Bacillus Coagulans for Enhanced Shelf Life. J App Biol Biotech. 2017; 5 (04): 057-065. 